\title{
PEMANFAATAN BAHAN BAKU LOKAL DI KLUNGKUNG, BALI UNTUK PAKAN IKAN NILA BEST (Oreochromis niloticus)
}

\author{
Mas Tri Djoko Sunarno, Irin Iriana Kusmini, dan Vitas Atmadi Prakoso\#
}

Balai Riset Perikanan Budidaya Air Tawar dan Penyuluhan Perikanan

(Naskah diterima: 24 Mei 2017; Revisi final: 8 November 2017; Disetujui publikasi: 8 November 2017)

\begin{abstract}
ABSTRAK
Tujuan penelitian ini adalah untuk mengaplikasikan pemanfaatan bahan baku lokal di Klungkung, Bali sebagai pakan ikan nila BEST dibandingkan dengan pakan komersil. Pemilihan bahan baku lokal untuk memformulasikan pakan uji ditentukan berdasarkan hasil survei bahan baku yang mengandung nutrien terbaik sesuai dengan kebutuhan ikan nila dan harga yang relatif murah. Pakan uji yang diformulasikan mengandung protein $29 \% 30 \%$ Performa pakan uji dibandingkan dengan pakan komersil dengan menggunakan uji-T. Setelah diaklimatisasi, benih ikan nila BEST (panjang total 5,7 $\pm 0,4 \mathrm{~cm}$; bobot 3,1 \pm $1,8 \mathrm{~g}$ ) ditebar secara acak ke dalam enam buah hapa berukuran $2 \mathrm{~m} \times 1 \mathrm{~m} \times 1 \mathrm{~m}$ yang terletak di dalam kolam $100 \mathrm{~m}^{2}$ dengan kepadatan 65 ekor $/ \mathrm{m}^{3}$ dan diberi pakan uji sebanyak 3\%dari total bobot seluruh ikan uji per hari selama tiga bulan masa pemeliharaan. Hasil penelitian menunjukkan bahwa pertumbuhan ikan nila BEST tidak berbeda nyata antara pakan uji hasil formulasi dengan pakan komersil $(P>0,05)$. Nilai FCR pakan komersil tidak berbeda nyata dibandingkan pakan formulasi. Berdasarkan hasil tersebut, keuntungan dengan menggunakan bahan baku lokal lebih tinggi dibandingkan dengan pakan komersil.
\end{abstract}

\section{KATA KUNCl: pakan lokal; pakan komersil; nila BEST; Oreochromis niloticus}

ABSTRACT: Utilization of locally found feed ingredients in Klungkung, Bali for Bogor Enhanced Strain Tilapia (BEST) Oreochromis niloticus diet. By: Mas Tri Djoko Sunarno, Irin Iriana Kusmini, and Vitas Atmadi Prakoso

The purpose of this study was to compare the utilization effects of locally found feed ingredients in Klungkung, Bali for BEST strain tilapia feed compared to a commercial feed. The selection of local raw ingredients used in the feed formulation was based on the best nutrient composition for tilapia needs and its price determined through a separate survey. Formulated test feed contained $29 \% 30 \%$ protein. The formulated feed performance was compared to the commercial feed using the T-test. After acclimatization, the fish (BEST strain tilapia, total length of $5.7 \pm 0.4 \mathrm{~cm}$; weight of $3.1 \pm 18 \mathrm{~g}$ ) were randomly stocked into six hapas, each measuring $2 \mathrm{~m} \times 1 \mathrm{~m} \times 1 \mathrm{~m}$ in size placed inside a pond $(100 \mathrm{~m} 2)$ with a density of 65 fish/m3 and fed $3 \%$ of the total fish biomass per day for three months rearing period. The results showed that the growth of BEST tilapia was not significantly different between the formulated feed and commercial feed ( $P>0.05)$. The FCR value of the commercial feed was not significantly different compared to the formulation feed. Based on these results, the benefit of using local raw materials was higher than that of commercial feed.

\section{KEYWORDS: local formulated diet; commercial diet; BEST tilapia; Oreochromis niloticus}

\section{PENDAHULUAN}

Ikan nila (Oreochromis niloticus) dikenal sebagai chicken freshwater karena populer di Indonesia dan di tingkat internasional. Salah satu cara untuk mempertahankan kualitas ikan nila di Indonesia adalah

\footnotetext{
\# Korespondensi: Balai Riset Perikanan Budidaya Air Tawar dan Penyuluhan Perikanan. Jl. Sempur No. 1, Bogor 16154 Indonesia. Tel. + 622518313200

E-mail: vitas.atmadi@gmail.com
}

dengan melakukan perbaikan genetika. Ikan nila BEST (Bogor Enhanched Strain Tilapia) merupakan salah satu hasil perbaikan genetika dengan keunggulan dari aspek pertumbuhan dan daya tahan terhadap lingkungan buruk dan penyakit dibandingkan ikan nila pendahulunya (Arifin et al., 2009).

Budidaya ikan adalah bisnis yang menguntungkan, namun biaya pakan ikan memiliki efek negatif yang signifikan terhadap profitabilitas (Ugwumba \& Chukwuji, 2010). Pada budidaya nila secara intensif, 
sekitar 70\%biaya produksi ikan nila digunakan untuk pembelian pakan, sementara itu suplai bahan baku pakan ikan di pasar dunia bervariasi dan harganya terus meningkat, sehingga pabrikan pakan yang mengandalkan bahan baku impor mengharuskan peningkatan harga pakan komersil. Oleh karena itu, formulasi pakan ikan secara tepat dengan menggunakan bahan baku lokal dapat mengurangi total biaya produksi dan meningkatkan keuntungan pembudidaya (Edwards \& Allan, 2004).

Sumber protein alternatif diperlukan untuk melengkapi atau mengganti pakan komersil, sehingga berkontribusi pada keberlanjutan jangka panjang industri budidaya (Tacon \& Jackson, 1985). Di beberapa negara, penggunaan sumber protein alternatif yang murah dan tersedia secara lokal sebagai pakan telah dilakukan, seperti di Kenya (Muchiri et al., 2015), Ghana (Obirikorang et al., 2015), Nigeria (Solomon \& Alasa, 2017), Thailand (Somsueb, 1993), dan Vietnam (Pucher et al., 2015).

Pakan buatan yang lengkap terdiri atas protein, karbohidrat, lemak, vitamin, dan mineral yang diperlukan untuk pertumbuhan dan kesehatan ikan yang optimal. Sebagian besar petani ikan nila menggunakan pakan lengkap, yang mengandung semua protein yang dibutuhkan $(18 \% 50 \%$, lemak $(10 \%$ $25 \%$, karbohidrat $(15 \% 20 \%$, abu $(<8,5 \%$, fosfor $<<$ $1,5 \%$ ), air (< 10\%), vitamin, dan mineral (Craig \& Helfrich, 2009), sementara itu pakan tambahan hanya ditujukan untuk mendukung pakan alami. Di Indonesia, upaya pembuatan pakan secara mandiri dengan menggunakan bahan baku lokal, namun kualitasnya masih di bawah pakan komersil (Sunarno et al., 2013) seperti yang diamati di Jawa Barat dan Jawa Tengah (Sunarno et al., 2012), Riau (Sunarno et al., 2013), dan Jambi (Sunarno \& Marson, 2012). Peningkatan kualitas pakan lokal dengan harga ekonomis telah diterapkan untuk ikan nila di Kabupaten Pandeglang (Kontara et al., 2013) dan Kabupaten Agam (Samsudin et al., 2013). Berdasarkan hal tersebut, perlu adanya penelitian mengenai pakan menggunakan bahan baku lokal dan pengujiannya pada ikan nila yang banyak dibudidayakan di wilayah lainnya. Salah satunya adalah di Klungkung, Bali. Penelitian ini bertujuan untuk menerapkan penggunaan bahan baku lokal di Klungkung, Bali untuk pakan ikan nila strain BEST (Oreochromis niloticus) dan juga dibandingkan dengan pakan komersil.

\section{BAHAN DAN METODE}

Penelitian dilakukan pada tahun 2014 di Kabupaten Klungkung Provinsi Bali. Kegiatan penelitian dibagi menjadi dua, yaitu survei bahan baku untuk mendapatkan jenis bahan baku yang dapat digunakan sebagai kandidat penyusun pakan formula dan pengujian pakan formula dari bahan baku setempat pada budidaya ikan nila BEST di kolam.

\section{Survei Bahan Baku}

Data yang dikumpulkan meliputi harga saat survei (tahun 2014) dan ketersediaan jenis bahan baku. Pada saat survei, 100-500 g sampel bahan baku pakan dan pakan komersil ikan nila yang biasa digunakan oleh pembudidaya, diambil secara acak dan disimpan dalam kantong plastik berlabel untuk dianalisis di Laboratorium Nutrisi, Balai Riset Perikanan Budidaya Air Tawar dan Penyuluhan Perikanan (BRPBATPP), Bogor. Data komposisi proksimat pakan uji digunakan sebagai pembanding untuk mengetahui ada tidaknya perbedaan terhadap pertumbuhan jika dibandingkan dengan pakan komersil.

\section{Percobaan Pakan Formula}

Pakan formula disusun menggunakan bahan baku lokal dengan mengacu kepada SNI untuk pembesaran ikan nila, yaitu mengandung protein sekitar $29 \% 30 \%$ Pakan ini dibuat oleh pembudidaya yang memproduksi pakan dibawah bimbingan peneliti. Prosedur pembuatan pakan mengacu kepada teknologi pakan sesuai standar (Sunarno et al., 2012). Pakan dibuat dalam bentuk pelet dengan diameter $3 \mathrm{~mm}$. Komposisi proksimat pakan uji dianalisis di Laboratorium Nutrisi BRPBATPP-Bogor, sebagai pembanding digunakan pakan komersil yang telah biasa digunakan oleh pembudidaya setempat.

Kolam milik pembudidaya yang berukuran $100 \mathrm{~m}^{2}$ digunakan untuk pemeliharaan benih ikan nila BEST di dalam enam buah hapa. Tiga buah hapa untuk perlakuan ikan yang diberi pakan dengan bahan baku lokal dan tiga buah hapa lainnya untuk perlakuan ikan yang diberi pakan komersil. Sebelum uji pertumbuhan dilakukan, kolam pemeliharaan diolah terlebih dahulu melalui beberapa tahap, yaitu pengeringan kolam, perbaikan pematang, pengolahan tanah dasar kolam, perbaikan saluran keluar dan masuk air, pengapuran dasar kolam, dan pemupukan dasar kolam. Kolam kemudian diisi air dengan menggunakan sumber air irigasi hingga kedalaman air kolam mencapai 1,5 m. Pengukuran beberapa parameter kualitas air seperti suhu, kecerahan, $\mathrm{pH}$, alkalinitas, dan amoniak-N dilakukan sebelum penebaran ikan.

Ikan nila BEST diambil dari Balai Benih Ikan, Kabupaten Tabanan. Benih tersebut diproduksi menggunakan induk yang berasal dari bantuan BRPBATPP, Bogor. Benih ikan nila BEST dengan panjang total 5,7 $\pm 0,4 \mathrm{~cm}$ dan bobot 3,1 $\pm 1,8 \mathrm{~g}$ ditebar secara acak ke dalam enam buah hapa (ukuran $2 \mathrm{~m} \times$ $1 \mathrm{~m} \times 1 \mathrm{~m}$ ) dengan kepadatan $65 \mathrm{ekor} / \mathrm{m}^{3}$ atau 130 
ekor per hapa. Ikan diberi pakan (perlakuan) tiga kali per hari pukul $08.00,12.00$, dan 17.00 sebanyak $3 \%$ dari bobot total ikan selama tiga bulan masa pemeliharaan. Sampling dilakukan dengan cara pengambilan sampel secara acak sebanyak 30 ekor per hapa dan masing-masing diukur panjang dan bobotnya. Pada akhir percobaan jumlah dan bobot ikan diukur. Parameter yang diamati yaitu pertumbuhan, sintasan, laju pertumbuhan spesifik (Huisman, 1987), dan konversi pakan. Analisis usaha budidaya ikan nila BEST menggunakan pakan komersil dan formula disajikan sebagai gambaran proyeksi keuntungan penggunaan kedua pakan tersebut. Pengaruh perlakuan terhadap parameter uji dianalisis secara statistik dengan uji-T pada tingkat kepercayaan $95 \%$

\section{HASIL DAN BAHASAN}

\section{Komposisi Proksimat Bahan Baku Lokal}

Hasil survei bahan baku lokal yang terdapat di Kabupaten Klungkung, Bali menunjukkan bahwa daerah ini memiliki bahan baku lokal yang dapat dimanfaatkan untuk pakan ikan, seperti tepung ikan lokal, kacang koro kualitas bawah standar, bungkil kelapa, dedak padi, polar, ampas tahu, jagung halus, dan rumput laut (Euchema dan Gracilaria). Bahan baku tersebut mudah didapat dengan harga yang memungkinkan untuk dijadikan sebagai bahan baku pakan ikan di Kabupaten Klungkung. Bahan baku yang dipakai dalam pembuatan pakan ini berfungsi sebagai sumber protein, sumber energi, mineral, dan vitamin. Faktor utama yang perlu diperhatikan dalam pemilihan bahan baku adalah: kandungan nutrisi bahan baku, tingkat kecernaan, ketersediaan, kontinuitas, dan harga.

Kecernaan protein masing-masing bahan pakan berbeda-beda. Bahan pakan yang berasal dari produk hewani secara umum lebih mudah dicerna dibanding produk nabati (Widodo, 2002). Pernyataan ini didukung oleh beberapa penelitian yang menyatakan bahwa pakan dengan protein hewani menghasilkan pertumbuhan yang lebih baik pada ikan dibandingkan pakan dengan protein nabati yang disebabkan kandungan asam amino esensial dalam bahan pakan tersebut (Cui et al., 1992; Refstie et al., 1998; Rahnema et al., 2005).

Sumber protein hewani yang terdapat di Kabupaten Klungkung berupa sisa proses pengolahan ikan tongkol berupa bagian sirip, kepala, dan usus ikan, dengan kadar air sekitar 52,1\% Dalam kondisi kering sisa tongkol ini kandungan proteinnya $54,6 \%$ Tepung ikan lokal mengandung protein $46,7 \%$ Bahan nabati yaitu kacang koro dengan kandungan protein $23,8 \%$ bungkil kelapa 13,8\% dan ampas tahu 13,3\%
Selain protein, sumber energi utama yang dibutuhkan oleh ikan adalah lemak. Lemak juga berpengaruh saat proses penyimpanan. Kadar lemak tinggi di sisi lain dapat membantu penyusunan ransum, namun kerugiannya yaitu cepat tengik atau mudah mengalami oksidasi asam lemak. Dari hasil survei, diketahui bahwa sumber lemak yang tinggi ada pada bungkil kelapa 24,7\% Sebagian besar ikan membutuhkan pakan dengan kandungan lemak antara $4 \% 8 \%$ (Afrianto \& Liviawaty, 2005). Menurut Mudjiman (2004), kebutuhan lemak untuk ikan air tawar berkisar $4 \% 18 \%$ sedangkan menurut standar makanan ikan minimal 3\% Hasil analisis proksimat pakan menunjukkan kadar lemak pakan komersil mencapai 5,0\% sedangkan pakan formulasi sebesar 12,3\% Pada pakan formulasi, sumber karbohidrat ada pada dedak halus. Menurut Sucipto \& Prihartono (2007), pertumbuhan ikan nila akan terlihat baik apabila diberi pakan dengan komposisi nutrisi yang seimbang, di mana di dalamnya terkandung bahan-bahan seperti protein, karbohidrat, lemak, vitamin, mineral, dan serat.

Dalam pembuatan pakan formula, tepung ikan yg digunakan masih relatif tinggi, yaitu sebanyak $48 \%$ Hal tersebut karena ketersediaannya yang melimpah di wilayah Kabupaten Klungkung dan harganya yang relatif murah, sehingga harga pakan formula masih lebih ekonomis dibandingkan dengan pakan komersil. Sama halnya dengan tepung ikan, pemilihan bahan baku lainnya seperti kacang koro, dedak halus, bungkil tahu, bungkit kelapa, dan rumput laut juga dipertimbangkan berdasarkan perhitungan ekonomis dan ketersediaannya di wilayah Kabupaten Klungkung. Hal ini sesuai dengan pernyataan dari Solomon \& Alasa (2017) dan Pucher et al. (2015) yang juga mengatakan bahwa penggunaan bahan baku alternatif yang tersedia secara lokal dapat menguntungkan pembudidaya melalui adanya subtitusi pakan komersil yang lebih mahal dengan pakan buatan yang harganya lebih murah.

Setelah diformulasi dan dicetak menjadi pelet, pakan formula berbasis bahan baku lokal ini diuji komposisi proksimatnya bersama dengan pakan komersial sebagai pembanding (Tabel 2).

Berdasarkan data komposisi proksimat, pakan komersil tidak memiliki perbedaan kandungan protein dengan pakan formula. Menurut SNI (2009), kandungan protein minimal untuk pembesaran ikan nila adalah $25 \%$ Pakan komersil mengandung abu dan serat kasar lebih rendah dari pakan formula. Kandungan abu dan serat kasar terlalu tinggi akan mengurangi tingkat kecernaan pakan tersebut (NRC, 1983; Lovell, 2014). Kandungan karbohidrat (BETN) pada pakan komersil juga lebih tinggi daripada pakan formula. 
Tabel 1. Formulasi pakan uji berbasis bahan baku lokal di Klungkung, Bali untuk ikan nila

Table 1. Formulation of tested feed using local raw materials available in Klungkung, Bali for tilapia

\begin{tabular}{|c|c|c|}
\hline & Bahan pakan (Feed ingredients) & $\begin{array}{c}\text { Komposisi } \\
\text { Composition (\%) }\end{array}$ \\
\hline \multicolumn{2}{|c|}{ Tepung ikan lokal (Local fish meal) } & 48.0 \\
\hline \multicolumn{2}{|c|}{ Kacang koro kualitas bawah standar (Below standard quality of jack bean ) } & 14.0 \\
\hline \multicolumn{2}{|c|}{ Dedak halus (Fine rice bran) } & 14.8 \\
\hline \multicolumn{2}{|c|}{ Bungkil kelapa (Coconut cake) } & 14.0 \\
\hline \multicolumn{2}{|c|}{ Bungkil tahu (Tofu cake) } & 2.5 \\
\hline \multicolumn{2}{|c|}{ Rumput laut (Euchema) / Seaweed (Euchema) } & 2.5 \\
\hline \multicolumn{2}{|c|}{ Minyak ikan (Fish oil) } & 1.2 \\
\hline \multicolumn{2}{|c|}{ Vitamin mix komersil (Commercial vitamin premix) } & 1.5 \\
\hline \multicolumn{2}{|c|}{ Mineral mix komersil (Commercial mineral premix ) } & 1.5 \\
\hline \multicolumn{2}{|r|}{ Total } & 100 \\
\hline \multicolumn{3}{|c|}{$\begin{array}{l}\text { Keterangan: Komposisi vitamin mix (mg/kg): *Vit. B1: } 200 \mathrm{mg} / \mathrm{kg} ; \mathrm{B} 2: 500 \mathrm{mg} / \mathrm{kg} ; \mathrm{B} 6: 50 \mathrm{mg} / \mathrm{kg} ; \\
\text { B12: } 1.200 .000 \mathrm{mc} . \mathrm{g} ; \text { Vit D3 (I.U): } 200.000 ; \text { Vit. E (I.U): 800; Vit. C: } 2.500 \mathrm{mg} / \mathrm{kg} ; \mathrm{Vit} \text { K } \\
\text { 200 mg/kg; Ca-D-Panthothenate: } 600 \mathrm{mg} / \mathrm{kg}\end{array}$} \\
\hline \multicolumn{3}{|c|}{ 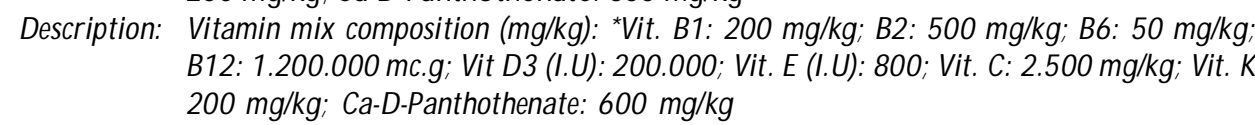 } \\
\hline
\end{tabular}

Tabel 2. Komposisi proksimat pakan untuk perlakuan uji pertumbuhan ikan nila

Table 2. Proximate composition of experimental diet fed to tilapia

\begin{tabular}{lcc}
\hline \multicolumn{1}{c}{$\begin{array}{c}\text { Komposisi proksimat } \\
\text { Proximate composition (\%) }\end{array}$} & PK & PF \\
\hline Protein (Crude protein) & 30.3 & 29.3 \\
Lemak (Crude lipid) & 5.0 & 12.3 \\
Abu (Ash) & 8.2 & 25.0 \\
Serat kasar (Crude fiber) & 11.7 & 14.2 \\
Bahan ekstrak tanpa nitrogen (BETN) & 44.8 & 19.2 \\
Nitrogen free extract (NFE) & & \\
\hline
\end{tabular}

Keterangan (Description): $\quad$ PK= pakan komersil; $P F=$ pakan formula bahan baku lokal $(P K=$ commercial diet; $P F=$ formulated diet from local materials)

BETN ini merupakan sumber energi nonprotein yang diharapkan dapat digunakan untuk pemenuhan energi pemeliharaan tubuh (Hardy, 2008; Kaushik, 2001). Lemak pakan juga merupakan sumber energi nonprotein yang lebih mudah dicerna daripada BETN (Lovell, 2014), selain sebagai sumber asam lemak esensial yang dibutuhkan untuk pertumbuhan ikan nila. Pada pakan komersil, kandungan lemaknya lebih rendah daripada pakan formula. Sumber lemak pakan formula berasal dari tepung ikan lokal dan minyak ikan. Penggunaan tepung ikan lokal pada pakan formula $(48 \%$ akan memudahkan kecernaan bahan tersebut dan diduga menyediakan asam amino esensial dan asam lemak esensial $(\omega-3)$ lebih tinggi (Hardy, 2008; Hetrampf \& Pascual, 2000) dibandingkan pakan komersil. Tepung ikan lokal mudah ditemui di Bali dan harganya kompetitif. Namun, penggunaan tepung ikan dalam pakan perlu dikurangi dan diganti dengan bahan baku lainnya (nabati dan hewani) (Lim et al., 2008). Oleh karena itu, pakan komersil relatif lebih baik dari aspek kadar abu dan serat kasar, dan pakan formula mempunyai keunggulan dari aspek asam amino esensial dan asam lemak esensial. 


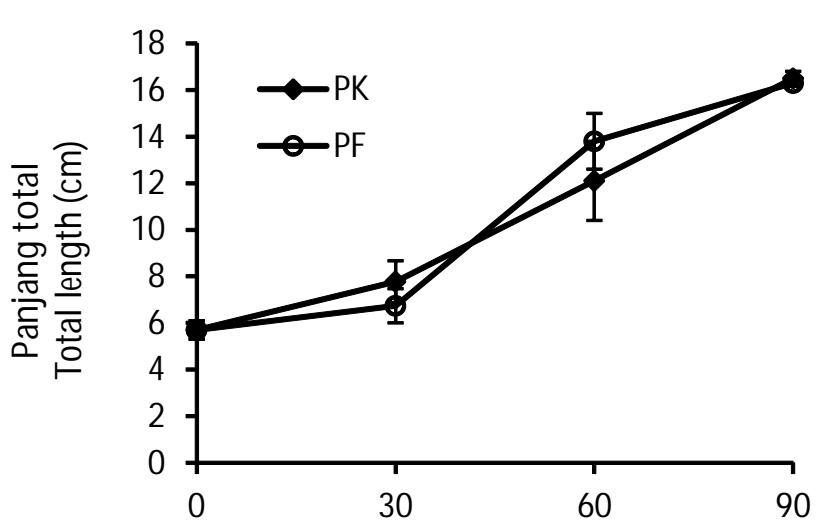

Waktu (hari) / Time (day)

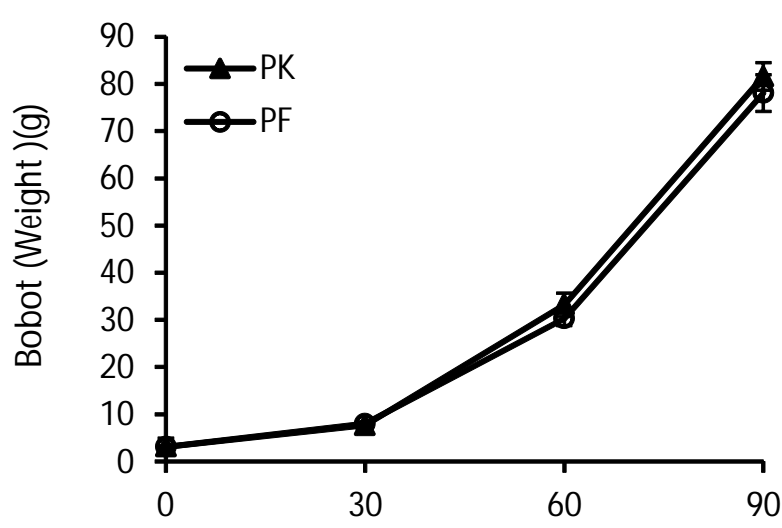

Waktu (hari) / Time (day)

Gambar 1. Panjang dan bobot ikan nila BEST ( $n=30$ ekor) selama pemeliharaan di Kabupaten Klungkung, Bali dengan pemberian pakan komersil dan pakan formula bahan baku lokal (Keterangan: PK= pakan komersil; $\mathrm{PF}=$ pakan formula bahan baku lokal).

Figure 1. Length and weight of BEST tilapia ( $n=30$ individu) during rearing period in Klungkung Regency of Bali fed with the commercial feed and formulated feed from locally available raw materials (Description: $\mathrm{PK}=$ commercial diet; $\mathrm{PF}=$ formulated diet from local materials).

\section{Pertumbuhan dan Sintasan Ikan Nila BEST}

Hasil penelitian menunjukkan bahwa penggunaan pakan yang berbeda tidak memberikan pengaruh nyata terhadap nilai pertumbuhan spesifik ikan uji $(P>0,05)$ (Gambar 1 dan Tabel 3).

Penggunaan pakan yang berbeda tidak memberikan pengaruh nyata $(P>0,05)$ terhadap pertumbuhan, sintasan, dan nilai konversi pakan uji. Konversi pakan menunjukkan rasio pakan yang diberikan dengan pertambahan biomassa ikan pada akhir dan awal penelitian. Penggunaan pakan bahan baku lokal menghasilkan konversi pakan ikan uji sebesar 1,2 \pm 0,1 sedangkan pakan komersil menghasilkan konversi pakan sebesar $1,1 \pm 0,1$. Hasil pengujian juga menunjukkan bahwa penggunaan pakan yang berbeda tidak memberikan pengaruh terhadap rasio konversi pakan.

Hasil percobaan menunjukkan bahwa penggunaan pakan formulasi memiliki nilai pertumbuhan yang tidak berbeda nyata dengan pakan komersil. Hal tersebut

Tabel 3. Keragaan pertumbuhan, sintasan, dan rasio konversi pakan ikan nila BEST umur tiga bulan di Kabupaten Klungkung, Bali dengan pemberian pakan komersial dan pakan bahan baku lokal

Table 3. Growth performance, survival rate, and feed conversion ratio of BEST tilapia after 3 months rearing period in Klungkung Regency of Bali fed with commercial feed and formulated feed with locally available raw materials

\begin{tabular}{lcc}
\hline \multirow{2}{*}{\multicolumn{1}{c}{ Parameter (Parameters) }} & \multicolumn{2}{c}{ Jenis pakan (Type of diet) } \\
\cline { 2 - 3 } & PK & PF \\
\hline Bobot awal (Initial weight) (g) & $3.1 \pm 0.8$ & $3.2 \pm 1.0$ \\
Bobot akhir (Final weight) (g) & $81.4 \pm 10.2$ & $78.1 \pm 4.9$ \\
Biomassa awal (Initial biomass) $(\mathrm{g})$ & $413.0 \pm 50.4$ & $426.5 \pm 33.2$ \\
Biomassa akhir (Final biomass) (g) & $7,074.1 \pm 351.2$ & $6,761.8 \pm 386.9$ \\
LPH (SGR ) (\%day) & $3.6 \pm 0.4$ & $3.6 \pm 0.1$ \\
Sintasan (Survival rate) (\%) & $67.7 \pm 10.1$ & $66.9 \pm 7.8$ \\
Rasio konversi pakan (Feed conversion ratio ) & $1.1 \pm 0.1$ & $1.2 \pm 0.1$ \\
\hline
\end{tabular}

Keterangan (Description): $\quad \mathrm{PK}=$ pakan komersil; $\mathrm{PF}=$ pakan formula bahan baku lokal (PK= commercial diet; $P F=$ formulated diet from local materials) 
menunjukkan bahwa penggunaan pakan berbasis bahan baku lokal dengan pakan komersil memiliki pengaruh yang tidak berbeda terhadap pertumbuhan ikan. Penelitian yang samajuga telah dilakukan oleh Suhenda et al. (2011) membandingkan penggunaan bahan baku lokal dengan pakan komersil untuk usaha pembesaran ikan lele di Kabupaten Banjarnegara. Hasilnya pakan dengan bahan baku lokal memiliki pertumbuhan yang tidak berbeda nyata dengan pakan komersil. Nilai konversi pakan pada pakan komersil sedikit lebih baik jika dibandingkan dengan pakan formula, namun tidak berbeda nyata $(P>0,05)$. Sintasan dan bobot panen ikan nila BEST juga tidak berbeda nyata antara pakan formula dengan pakan komersil $(P>0,05)$ (Tabel 3). Hal ini menunjukkan bahwa penggunaan pakan berbasis bahan baku lokal memiliki kualitas yang sebanding dengan pakan komersil, sehingga dapat digunakan oleh pembudidaya.

Berdasarkan hasil uji pertumbuhan pada penelitian ini, dilakukan perhitungan analisis usaha budidaya ikan nila BEST di kolam dengan asumsi menggunakan kolam
$5 \mathrm{~m} \times 4 \mathrm{~m} \times 1,5 \mathrm{~m}\left(30 \mathrm{~m}^{3}\right)$ dan kepadatan 2.000 ekor per kolam. Parameter konversi pakan dan panen ikan mengacu kepada hasil penelitian. Hasil perhitungan analisis usaha menunjukkan bahwa keuntungan dengan penggunaan pakan berbasis bahan baku lokal lebih tinggi jika dibandingkan dengan pakan komersil (Tabel 4). Selain memiliki kualitas yang baik sesuai dengan kebutuhan biologis ikan, pakan berbasis bahan baku lokal juga harus dapat menekan tingginya harga pakan. Menurut Devani \& Basriati (2015), yang menggunakan metode Multi Objective (Goal) Programming dalam membuat permodelan untuk pakan ikan air tawar, menyimpulkan bahwa pembudidaya ikan dapat menghemat biaya operasional sebesar $20 \%$ dengan membuat pakan buatan. Terkait dengan informasi tersebut, dibandingkan dengan pakan komersil, pakan dengan bahan baku lokal (formula BRPBATPP) lebih efisien. Dalam hal ini dapat dilihat dari proyeksi keuntungan yang diperoleh dengan perbedaan harga pakan sebesar Rp3.000,00/kg dari harga pakan komersil. Perbedaan harga pakan tersebut masih

Tabel 4. Analisis usaha ikan nila BEST (0. niloticus) yang diberi pakan komersil dan pakan formula selama tiga bulan masa pemeliharaan di Kabupaten Klungkung, Bali

Table 4. Business analysis of BEST tilapia (0. niloticus) fed with commercial diet and formulation diet from local raw materials and reared for three months rearing in Klungkung Regency of Bali

\begin{tabular}{|c|c|c|}
\hline \multirow{2}{*}{ Uraian (Illustration) } & \multicolumn{2}{|c|}{ Jenis pakan (Type of diet) } \\
\hline & PK & PF \\
\hline \multicolumn{3}{|l|}{ Biaya Operasional (Operational cost) } \\
\hline $\begin{array}{l}\text { Persiapan kolam } \\
\text { Pond preparation }\end{array}$ & Rp150,000.00 & Rp150,000.00 \\
\hline $\begin{array}{l}\text { Benih ikan (Asumsi: } 2.000 \text { ekor } \times \text { Rp375,00 per ekor) } \\
\text { Fish seedling (Assumption: 2,000 } \times \text { Rp375.00 per fish) }\end{array}$ & Rp750,000.00 & Rp750,000.00 \\
\hline $\begin{array}{l}\text { Rata-rata pakan } \\
\text { Average of feed }\end{array}$ & Rp1,099,100.00 $\pm 57,950$ & Rp798.300.00 $\pm 48,750$ \\
\hline $\begin{array}{l}\text { Bahan bantu (serok, ember) } \\
\text { Equipment (scope net, bucket) }\end{array}$ & Rp150,000.00 & Rp150,000.00 \\
\hline $\begin{array}{l}\text { Jumlah } \\
\text { Total }\end{array}$ & $\mathrm{Rp2}, 149,100.00 \pm 57,950$ & $\mathrm{Rp} 1,839,300.00 \pm, 48,750$ \\
\hline \multicolumn{3}{|l|}{ Keuntungan (Profits) } \\
\hline $\begin{array}{l}\text { Rata-rata total panen (kg per siklus) } \\
\text { Average of total yield (kg per cycle) }\end{array}$ & $108.8 \pm 5.4$ & $104.1 \pm 5.9$ \\
\hline $\begin{array}{l}\text { Rata-rata pendapatan } \\
\text { Average income }\end{array}$ & $\mathrm{Rp} 2,394,300.00 \pm 118,900$ & $\mathrm{Rp} 2,288,600.00 \pm, 131,000$ \\
\hline $\begin{array}{l}\text { Rata-rata keuntungan per siklus } \\
\text { Average of profits per cycle }\end{array}$ & $\mathrm{Rp} 245,200.00 \pm, 60,950$ & Rp449,300.00 $\pm, 82,250$ \\
\hline $\begin{array}{l}\text { Keterangan: Harga pakan komersial: Rp10.000,00/kg; harga } \\
\text { terbaru ikan nila di Provinsi Bali: Rp22.000,00/k } \\
\text { Description: Commercial diet price: Rp10,000.00/kg; formulat }\end{array}$ & $\begin{array}{l}\text { akan formula: Rp7.000,00/kg; sc } \\
\text { (Suendi, 2016) } \\
\text { on diet price: Rp7,000.00/kg; one }\end{array}$ & $\begin{array}{l}\text { tu siklus: tiga bulan; harga jual } \\
\text { cycle: three months; update }\end{array}$ \\
\hline
\end{tabular}


relevan sampai saat ini, sehingga keuntungan yang diperoleh dari penggunaan bahan baku lokal lebih tinggi dibandingkan dengan penggunaan pakan komersil.

\section{KESIMPULAN}

Penggunaan pakan formula dengan bahan baku lokal di Kabupaten Klungkung, Bali memberikan respons pertumbuhan yang sama dengan penggunaan pakan komersil untuk ikan nila BEST dan menghasilkan efisiensi, serta keuntungan yang lebih tinggi. Pakan formula dengan bahan baku lokal ini dapat diterapkan untuk pemeliharaan ikan nila BEST.

\section{UCAPAN TERIMA KASIH}

Penulis mengucapkan terima kasih kepada Bapak drh. I Gusti Ngurah Badiwangsa beserta staf Dinas Peternakan, Perikanan dan Kelautan Klungkung, Bali. Ucapan terima kasih juga disampaikan kepada Bpk. Budi Nugraha, M.Si. yang telah banyak memfasilitasi terlaksananya kegiatan ini.

\section{DAFTAR ACUAN}

Arifin, O.Z., Huwoyon, G.H., \& Gustiano, R. (2009). Keragaan pertumbuhan ikan nila hitam (BEST) dan nila merah (NIFI) (Oreochromis niloticus) dalam pemeliharaan terpisah di kolam. Prosiding Seminar Nasional Tahunan VI Hasil Penelitian Perikanan dan Kelautan, Yogyakarta, 25 Juli 2009. Djumanto et al. (Penyunting), GN-04. Jurusan Perikanan dan Kelautan Fakultas Pertanian Universitas Gadjah Mada. $10 \mathrm{hlm}$.

Afrianto, E. \& Liviawaty, E. (2005). Pakan ikan. Kanisius: Yogyakarta, $148 \mathrm{hlm}$.

Craig, S. \& Helfrich, L.A. (2009). Understanding fish nutrition, feeds, and feeding. Virginia Cooperative Extension, 420(256), 7-19.

Cui, Y., Liu, X., Wang, S., \& Chen, S. (1992). Growth and energy budget in young grass carp (Ctenopharyngodon idella) fed plant and animal diets. Journal of Fish Biology, 48, 231-238.

Devani, V. \& Basriati, S. (2015). Optimasi kandungan nutrisi pakan ikan buatan dengan menggunakan multi objective (Goal) programing model. Jurnal Sains Teknologi dan Industri, 12(2), 255-261.

Edwards, P. \& Allan, G.L. (2004). Feeds and feeding for inland aquaculture in Mekong region countries. Australian Centre for International Agricultural Research, Technical Report, 56, 1-136.

Hardy, R.W. (2008). Farmed fish diets requirements for the next decade and implications for global availability of nutrients. In Lim, C., Webster, C.D.,
\& Lee, C. (Eds.), Alternative protein sources in aquaculture diets. New York: The Haworth Press, Taylor \& Francis Group, p. 1-16.

Hetrampf, J.W. \& Pascual, P.P. (2000). Handbook on ingredients for aquaculture feeds. London: Kluwer Academic Publishers, 567 pp.

Huisman, E.A. (1987). Principle of fish production. Department of Aquaculture, Wageningen University. Netherlands, $170 \mathrm{pp}$.

Kaushik, S.J. (2001). Carbohydrate nutrition: Importance and limits of carbohydrate supplies. In Guillaume, J., Kaushik, S., Berbot, P., \& Metailler, R. Nutrition and feeding of fish and crustaceans. Chichester, UK: Praxis Publishing, p. 131-144.

Kontara, E.K., Samsudin, R., \& Sunarno, M.T.D. (2013). Pengembangan budidaya ikan nila (Oreochromis niloticus) di kolam tanah dengan aplikasi pakan berbasis bahan baku lokal. Prosiding Forum Inovasi Teknologi Akuakultur 2013, Nusa Tenggara Barat, 1113 Juni 2013. Haryanti, Rahmansyah, Radiarta, I N., Kristanto, A.H., Imron, Sugama, K., Pantjara, B., \& Azwar, Z.I. (Penyunting). Pusat Litbang Perikanan Budidaya, hlm. 501-506.

Lim, C., Webster, C.D., \& Lee, C. (2008). Nutrition and feeding of fish and crustaceans. Chichester, UK: Praxis Publishing, $571 \mathrm{pp}$.

Lovell, R.L. (2014). Nutrition of aquaculture species. Journal of Animal Science, 69, 4193-4200.

Muchiri, M.N., Nanua, J.N., \& Liti, D. (2015). A comparative study on growth, composition and sensory quality between farmed and wild nile tilapia (Oreochromis niloticus). Net Journal of Agricultural Science, 3(2), 56-61.

Mudjiman, A. (2004). Makanan ikan. Jakarta: Penebar Swadaya, $190 \mathrm{hlm}$.

National Research Council [NRC]. (1983). Nutrient requirements of fish. Washington DC, US: National Academy of Science, 114 pp.

Obirikorang, K.A., Amisah, S., Agbo, N.W., AdjeiBoateng, D., Adjei, N.G., \& Skov, P.V. (2015). Evaluation of locally-available agroindustrial by products as partial replacements to fishmeal in diets for nile tilapia (Oreochromis niloticus) production in Ghana. Journal of Animal Research and Nutrition, 1(1), 1-9.

Pucher, J., Mayrhofer, R., El-Matbouli, M., \& Focken, U. (2015). Pond management strategies for smallscale aquaculture in northern Vietnam: fish production and economic performance. Aquaculture International, 23, 297-314.

Rahnema, S., Borton R., \& Shaw, E. (2005). Determination of the effects of fish vs plant vs meat pro- 
tein-based diets on the growth and health of rainbow trout. Journal of Applied Animal Research, 27(2), 77-80.

Refstie, S., Storebaken, T., \& Roem, A.J. (1998). Feed consumption and conversion in Atlantic salmon (Salmo salar) fed diets with fish meal, extracted soybean meal or soybean meal with reduced content of oligosaccharides, trypsin inhibitors, lectins and soya antigens. Aquaculture, 162, 301-312.

Samsudin, R., Sunarno, M.T.D., \& Sulhi, M. (2013). Inovasi pakan efisien dan ekonomis berbasis bahan baku lokal untuk pembesaran ikan nila (Oreochromis niloticus). Prosiding Hasil Penelitian Terbaik Tahun 2013, Jakarta, 12-13 November 2013. Hanggono, A., Ferindera, T.D., Gumilar, H., \& Kurniawan D. (Penyunting), Badan Litbang Kelautan dan Perikanan, hlm. 208-216.

SNI. (2009). SNI 7550:2009, Standar Nasional Indonesia. Produksi ikan nila (Oreochromis niloticus Bleeker) kelas pembesaran di kolam air tenang. ICS 65.120.

Solomon, R.J. \& Alasa, M.B. (2017). Performance and survival of Clarias gariepinus from locally processed corn and soya bean meal as a replacement for fish meal. Journal of Animal Science and Veterinary M edicine, 2, 38-45.

Somsueb, P. (1993). Aquafeeds and feeding strategies in Thailand. Farm-made aquafeeds. Proceedings of the FAO/AADCP Regional. Bangkok, Thailand, p. 358365.

Sucipto, A. \& Prihartono, E. (2007). Pembesaran ikan nila merah bangkok. Jakarta: Penebar Swadaya, 111 $\mathrm{hlm}$.

Suendi, I.K. (2016). Harga 6 komoditi perikanan di tingkat produsen. http://www.diskelkan. baliprov.go.id/diakses pada tanggal 9 Oktober 2016.

Suhenda, N., Mulyasari, Melati, I., Nugraha, A., \& Teguh. (2011). Pemanfaatan bahan baku hewani dalam pakan ikan jenis Catfish. Laporan Kegiatan
Seminar Hasil Riset 2011, Cipanas, Desember 2011. Wakhid, A., Sulhi, M., \& Arifin, O.Z. (Penyunting). Balai Litbang Budidaya Air Tawar, hlm. 153-174.

Sunarno, M.T.D., Sulhi, M., \& Suryaningrum, L.H. (2013). Kajian pabrik pakan ikan lokal dalam mendukung industrialisasi budidaya patin (Pangasius sp.) di Kabupaten Kampar Provinsi Riau. Prosiding Forum Inovasi Teknologi Akuakultur 2013, Nusa Tenggara Barat, 11-13 Juni 2013. Haryanti, Rahmansyah, Radiarta, I N., Kristanto, A.H., Imron, Sugama, K., Pantjara, B., \& Azwar, Z.I. (Penyunting). Pusat Litbang Perikanan Budidaya, hlm. 371-379.

Sunarno, M.T.D. \& Marson. (2012). Swampy area for development of patin culture. Proceeding International Conference on Indonesia Inland Waters III, Palembang, 8 November 2012. Suman et al. (Eds). Research Institute for Inland Fisheries, p. 57-63

Sunarno, M.T.D., Sulhi, M., Samsudin, R., Kurnasih, T., Wilakstanti, M., Mulyasari, \& Suryaningrum, L.H. (2012). Formulasi pakan ikan berbasis bahan baku hijauan. Laporan Kegiatan Seminar Hasil Riset 2012, Bogor, Desember 2012. Nuryadi et al. (Penyunting). Balai Litbang Budidaya Air Tawar, hlm. 67-94.

Tacon, A.G.J. \& Jackson, A.J. (1985). Utilization of conventional and non-conventional protein sources in practical fish feeds. In Nutrition and Feeding of Fish. Cowey, C.B., Mackie, A.M., \& Bell, J.G. (Eds.). London: Academic Press, p. 119145.

Ugwumba, C.O.A. \& Chukwuji, C.O. (2010). The economics of catfish production in Anambra State, Nigeria: A profit function approach. Journal of Agriculture and Social Sciences, 6, 105-109.

Widodo, W. (2002). Nutrisi dan pakan unggas kontekstual. Jakarta: Direktorat Jenderal Pendidikan Tinggi Depdiknas, $286 \mathrm{hlm}$. 